\title{
Population dynamics of the rat Microryzomys minutus (Rodentia: Muridae) in the Venezuelan Andes
}

\author{
Daniel R. Cabello, Guillermo Bianchi-Perez \& Paolo Ramoni-Perazzi \\ Facultad de Ciencias. Departamento de Biología. Universidad de Los Andes. Mérida 5101. Venezuela. fax: 58-274- \\ 240-1286; cabellod@ula.ve
}

Received 26-III-2003. C Corrected 06-XI-2003. Accepted 29-VI-2004.

\begin{abstract}
The population dynamics of the small forest rice rat Microryzomys minutus, a murid rodent that occurs in the high altitudes of the northern and central Andes, was studied in disturbed and primary environments in a cloud forest of the Venezuelan Andes (Juan Pablo Peñaloza National Park, $8^{\circ} 11^{\prime} \mathrm{N}, 71^{\circ} 49^{\prime} \mathrm{W}$ ). We collected 121 animals (66 OO and $55 \sigma^{\top} \sigma^{\top}$ ) between 1995 and 1998, using pitfall traps with formalin. Adult males were heavier than adult females. Relative abundance was much greater in the disturbed environments (over 10 individuals in some periods) than in the primary cloud forest: 4-8 individuals. In the disturbed environments, the rats were extremely abundant in the first sampling period, and less frequent afterwards. In the cropland, abundance showed some fluctuations during the study and displayed two small abundance peaks in March-June 1997 and 1998. In the mined area, the rats had irregular fluctuations until March-June 1997 and were not recorded in July-October 1997. The occurrence of this rat in both disturbed and natural habitats confirms the wide ecological tolerance of this species. Rev. Biol. Trop. 54(2): 651-. Epub 2006 Jun 01.
\end{abstract}

Key words: neotropical rodents, Muridae, cloud forest, Microryzomys minutus, Venezuela.

Microryzomys minutus (Tomes 1860) is a murid rodent that occurs in the high altitudes of the northern and central Andes (Walker 1975, Handley 1976, Carleton and Musser 1989, Eisenberg 1989, Linares 1998). This species is classified as sylvan and terrestrialscansorial, and moves freely between forested and open habitat types (Hershkovitz 1972, Aagaard 1982). M. minutus prefers the forest floor and forages on the ground, where it consumes large amounts of Renealmia sp. and palm seeds (Díaz de Pascual 1994), although it is associated with arboreal vegetation and can climb (Eisenberg 1989). It breeds at the beginning of the rainy season; litter size is about three or four specimens (Linares 1998).

M. minutus is epidemically significant, individuals coming from populations surveyed in coffee plantations in SW Colombia have been found infected with parasites of the Leishmania braziliensis complex and might therefore act as reservoirs of human cutaneous leishmaniasis (Alexander et al. 1998).

The forest small rice rat can be considered as a common species in the cloud forest since it is frequently observed and regularly encountered by farmers who report this rat as a plague at their dwellings; however, the ecology of the species is almost unknown, probably due to its quite low capture rate when using standard live-trapping techniques (Bianchi-Pérez 1997). This fact, and some data in the literature showing pitfall traps efficiency in comparison to live traps to collect very small animals (Handley and Kalko 1993, Kalko and Handley 1993, Stanko et al. 1999), lead us to sample the rodents with pitfall traps. The aim of this research was to study the population abundance 
and structure of $M$. minutus in disturbed (mined areas and croplands) and primary environments in a cloud forest of the Venezuelan Andes.

\section{MATERIAL AND METHODS}

Study Area. The study site was in the northern border of the Juan Pablo Peñaloza National Park ( $8^{\circ} 11^{\prime}$ N, $71^{\circ} 49^{\prime}$ W), 7 km S from the town of Bailadores, Venezuela, between 2000 and $2800 \mathrm{~m}$ asl (Fig. 1). Total annual precipitation ranges greatly from 636 to $1514 \mathrm{~mm}$ with rainy peaks in April-May and SeptemberNovember, while the least humid period is January-February; really dry months do not occur in the study area. Mean monthly temperature varies little throughout the year and averages $16.4^{\circ} \mathrm{C}$.

The vegetation has been described as a low humid forest (Ewel et al. 1976). The canopy is some 20 to $25 \mathrm{~m}$ height and is constituted by Podocarpus oleifolium, Clusia sp., Weinmannia sp., Trema sp. and some Lauraceae. The genera Inga, Miconia, Psidium, Piper, Renealmia and Croton dominate the understory. The secondary forest is originated from the abandon of some areas utilized for farming. The regeneration forms a small tree open forest dominated mainly by Weinmannia sp. Main families are Mirtaceae, Clusiaceae, Arecaceae, Solanaceae, Melastomataceae, Asteraceae, Zingiberaceae and Moraceae. Pteridium sp., Rubus sp. and Chusquea sp. characterize the open parts. Besides, there are many farms and some polysulphide ore smelters inside this National Park.

Rodents were sampled at three trapping stations: two located in disturbed forests: one around an abandoned mine (2400 $\mathrm{m}$ asl), and the other in a secondary forest $(2600 \mathrm{~m}$ asl) near farms. The third station was in a primary cloud forest (2000 m asl). Each station consisted of one transect with 30 traps located about $10 \mathrm{~m}$ apart. Traps consisted of $1 \mathrm{~kg}$ plastic containers, with a hole drilled at each side, about 5 $\mathrm{cm}$ below the tops to prevent overflows when it rains. Traps were filled with 0.251 of $10 \%$ formalin solution plus $1 \mathrm{~g}$ of powdered soap. Traps were checked monthly from July 1995 to June 1998. Trapping in the primary cloud forest began in March 1997.

We determined sex, reproductive stage and standard morphometric data of collected animals. Weight was estimated by drying wet fur of rats to constant weight by means of a

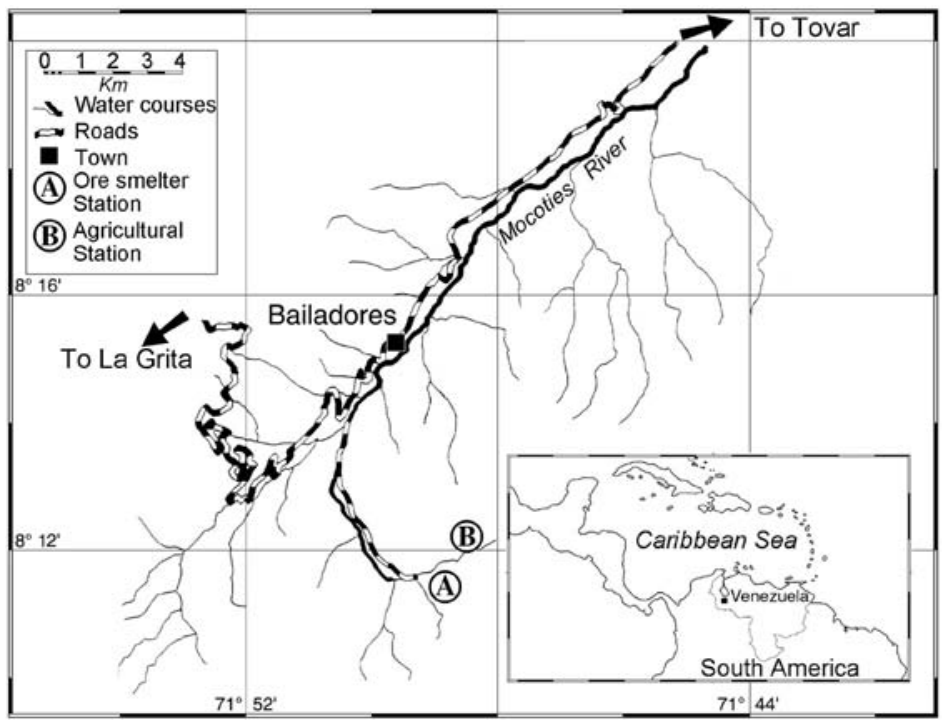

Fig. 1. Geographical location of the study area.

lamp; then each animal was weighed and a correction factor ( $10 \%$ of body weight) was added. This correction factor was determined replicating formaldehyde immersion conditions in the lab using house mice (Mus muscu$l u s)$ as a biological model. Males with scrotal testes, and females with perforated vagina, pregnant or lactating were considered sexually active adults. Collected specimens were deposited in the Colección de Vertebrados of the Universidad de Los Andes (CVULA); 
registered catalogue numbers were I-6607 to I-6727. Animal tissues were kept for further heavy metals chemical analysis to be published elsewhere.

\section{RESULTS}

Population abundance. A total of 121 individuals were collected. Because of low number of animals caught in some months, abundance was estimated as the number of captured individuals by 30 traps in each fourmonths period.

Relative abundance was much greater in the disturbed environments (over 10 individuals in some periods) than in the primary cloud forest: 4-8 individuals (Fig. 2). In the disturbed environments, in the first sampling period, rat numbers were extremely higher than those in the following ones, when abundance was relatively low. In the croplands, animal abundance showed some fluctuations during the study and displayed two small abundance peaks in March-June 1997 and 1998. In the mined area, rats presented some irregular fluctuations until March-June 1997 and were not recorded in the period July-October 1997. From November 1997 to June 1998, they had a small increase in their numbers.

In the primary cloud forest, low fluctuations occurred in rat abundance with a small increase in the last sampling period. Contrasting with disturbed forests, there was not a steep decrease in the collected number of animals.

Population structure. Juvenile rats were more abundant (3-7 individuals) at the least rainy months while their lowest abundance (0-1 individuals) was registered at the precipitation peaks (Fig. 3). More females than males were captured, but the difference was neither consistent nor significant (Table 1).

Body weight. In the study area, all sexually active rats weighed more than $11 \mathrm{~g}$. Overall, adult males were heavier than adult females $(t=3.359 ; p=0.001)$. However, no significant

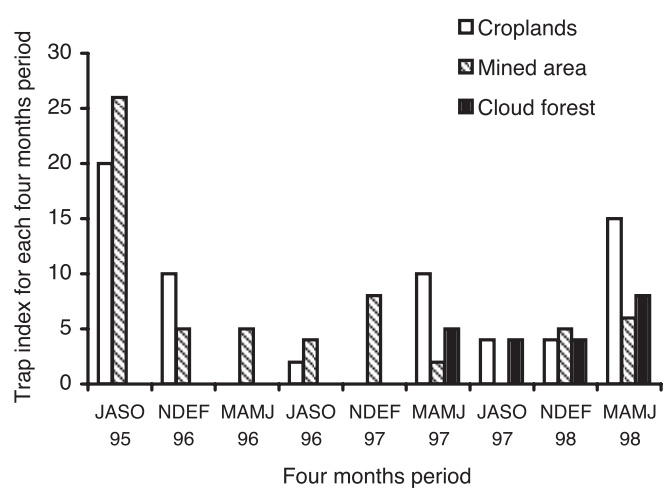

Fig. 2. Relative abundance of Microryzomys minutus in a cloud forest of the Venezuelan Andes.

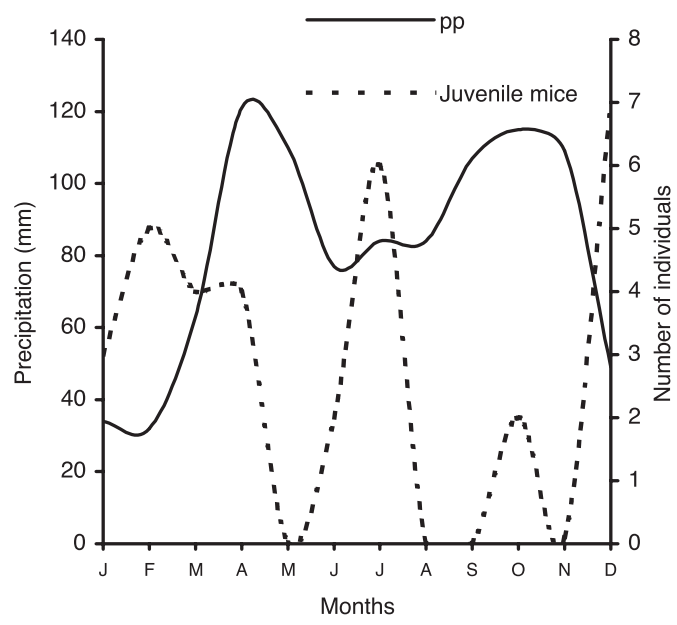

Fig. 3. Relation between juvenile number and precipitation in Microryzomys minutus in a cloud forest of the Venezuelan Andes.

difference between sexes was registered in animals from croplands and the primary cloud forest (Table 1). Mean weight for females from the cloud forest was lighter than those from other sites $(F=5.756 ; p=0.006)$. Mean weight of males did not change among sites.

\section{DISCUSSION}

The presence of forest small rice rat in disturbed and primary habitats agrees with other observations (Hershkovitz 1972, Handley 
TABLE 1

Mean adult body weights (g). $\mathrm{t}$-test values are significant if $\mathrm{p}<0.05$

\begin{tabular}{lcccccccc}
\multicolumn{1}{c}{ Habitat } & Males & SD & $\mathrm{n}$ & Females & SD & $\mathrm{n}$ & $\mathrm{t}$-Test & Likelihood \\
Cropland & 15.32 & 3.13 & 19 & 13.87 & 1.39 & 23 & 1.995 & Non significant \\
Cloud Forest & 14.17 & 2.48 & 6 & 11.33 & 0.58 & 3 & 1.888 & Non significant \\
Mined Area & 15.50 & 3.03 & 14 & 13.65 & 1.07 & 23 & 2.681 & $p=0.011$ \\
Total & 15.21 & 2.97 & 39 & 13.61 & 1.34 & 49 & 3.359 & $p=0.001$
\end{tabular}

n, number of specimens; SD, standard deviation.

1976, Aagaard 1982, Eisenberg 1989) confirming the wide ecological tolerance of this species. However, abundance variations in the different biotopes suggest the importance of several environmental parameters, such as food, cover, and predators (Gurnell 1985, King 1985). M. minutus is the most abundant rodent in the Venezuelan cloud forests because of its body size and the presence of plenty of shelters, such as rocks, holes, roots and a very stratified understory (Handley 1976, Aagaard 1982, Eisenberg 1989). However, this species is not always reported as the most abundant (Aagaard 1982, Díaz de Pascual 1994) in cloud forests, probably because trapping with live traps does not capture these light animals.

Young rats were collected in almost all months suggesting the lack of a clearly defined reproductive season; in contrast with Linares (1998) who indicated that M. minutus breeds at the beginning of rains. It could be a consequence of food availability throughout the year (Seres and Ramírez 1993) and the absence of a real dry season. Although food availability is greatest when palm seedlings are more abundant (Ataroff and Schwarzkopf 1992), rats can eat other items as Renealmia sp. fruits, which are available during the whole year (Seres and Ramírez 1993), and obtain energy enough to breed at any time. So, in the study area, M. minutus populations seem to be different from many small rodents that are seasonal breeders and initiate their reproduction when energy and nutrients reach a certain threshold level (Ims 1987).

Our results agreed with Aagaard (1982) who indicated that males were about 18 percent heavier than females in the Sierra Nevada National Park. On the other hand, forest small rats living in the cloud forests around Bailadores seem to be heavier than those from other localities in the Venezuelan Andes. The specimens collected in the study area averaged almost $14 \mathrm{~g}$, in contrast with Díaz de Pascual (1994) who reported a mean weight of $11.4 \mathrm{~g}$ in the Monte Zerpa cloud forest, some $100 \mathrm{~km} \mathrm{NE}$ from our study area. Furthermore, differences in body weight and number of collected specimens between the primary cloud forest and the disturbed habitats could be consequence of differences in food availability. Since cultivation and early successional stages can achieve yields far in excess of those of the primary production of naturally plant communities of a particular region (Larcher 1995).

\section{ACKNOWLEDGMENTS}

We thank H. Marquina for field help, A. Mora and J. Mora-Molina for housing facilities and two anonymous reviewers for improving the original manuscript. The study was supported by a grant from the Universidad de Los Andes, Mérida, Venezuela (CDCHT-ULA C904-98-01-A) to the first author. 


\section{RESUMEN}

Se analizó la dinámica poblacional de las pequeñas ratas silvestres del arroz Microryzomys minutus en ambientes alterados y primarios, en un bosque nublado de los Andes venezolanos. El estudio fue basado en 121 animales (66 우 y $\left.55 \sigma^{\top} ठ^{\top}\right)$ recolectados entre 1995 y 1998 , usando trampas que contenían formalina. Esta especie está presente en ambos hábitats lo que confirma su amplia tolerancia ecológica. La abundancia poblacional fue mayor en ambientes alterados que en los no alterados. M. minutus presenta dimorfismo sexual en el peso: los machos son más pesados que las hembras.

Palabras clave: roedores, neotrópico, Muridae, bosque nublado, Microryzomys minutus, Venezuela.

\section{REFERENCES}

Aagaard, E.M.J. 1982. Ecological distribution of mammals in the cloud forests and paramos of the Andes, Mérida, Venezuela. Ph.D.Thesis. Colorado State University, Fort Collins, Colorado, USA. 277 p.

Alexander B., C. Lozano, D.C. Barker, S.H.E. McCann \& G.H. Adler. 1998. Detection of Leishmania (Viannia) braziliensis complex in wild mammals from Colombian coffee plantations by PCR and DNA hybridization. Acta Trop. 69: 41-50.

Ataroff, M. \& T. Schwarzkopf. 1992. Leaf production, reproduction patterns, field germination and seedling survival in Chamaedorea bartlingiana, a dioecious undestory palm. Oecologia 92: 250-256.

Bianchi-Pérez, G. 1997. Niveles de Pb, Cd, Cu y Zn en tejidos de roedores asociados a los yacimientos de sulfuros masivos de Bailadores, Estado Mérida, Venezuela. Tesis de Licenciatura. Universidad de Los Andes, Mérida, Venezuela. 66 p.

Carleton, M.D. \& G.G. Musser. 1989. Systematic studies of oryzomyine rodents (Muridae, Sigmodontinae): A synopsis of Microryzomys. Bull. Am. Mus. Nat. Hist. 191: 1-83.

Díaz de Pascual, A. 1994. The rodent community of the Venezuelan cloud forest, Mérida. Pol. Ecol. Studies 20: $155-161$.

Eisenberg, J.F. 1989. Mammals of the Neotropics. The Northern Neotropics. Vol. 1. The University of Chicago. Chicago, Illinois. 449 p.

Ewel, J.J., A. Madriz \& J.A. Tosi. 1976. Zonas de vida de Venezuela. Memoria explicativa sobre el mapa ecológico. Ministerio de Agricultura y Cría. Fondo Nacional de Investigaciones Agropecuarias. Caracas. Venezuela. 271 p.

Gurnell, J. 1985. Woodland rodent communities. Symp. Zool. Soc. London. 55: 377-411.

Handley, C.O. Jr. 1976. Mammals of the Smithsonian Venezuelan Project. Brigham Young Univ. Sci. Bull. 20: 1-91.

Handley, C.O. Jr. \& E.K.V. Kalko. 1993. A short history of pitfall trapping in America, with a review of methods currently used for small mammals. Virginia J. Sci. 44: 19-26.

Hershkovitz, P. 1972. The recent mammals of the Neotropical region: a zoogeographical and ecological review, p. 311-431. In A. Keast, F.C. Erk \& B. Glass (eds.). Evolution, mammals and Southern continents. Albany State Univ. New York, Albany, New York, USA.

Ims, R.A. 1987. Male spacing systems in microtine rodents. Amer. Natur. 130: 474-485.

Kalko, E.K.V. \& C.O. Handley, Jr. 1993. Comparative studies of small mammals populations with transects of snap traps and pitfall arrays in southwest Virginia. Virginia J. Sci. 44: 3-18.

King, C.M. 1985. Interaction between woodland rodents and their predators. Symp. Zool. Soc. London 55: 219-247.

Larcher, W. 1995. Physiological plant ecology: ecophysiology and stress physiology of functional groups. Springer, Berlin. 506 p.

Linares, O.J. 1998. Mamíferos de Venezuela. Sociedad Conservacionista Audubon de Venezuela, Caracas. $691 \mathrm{p}$.

Seres, A. \& N. Ramírez. 1993. Flowering and fructification of monocotyledons in a Venezuelan cloud forest. Rev. Biol. Trop. 41: 27-36.

Stanko, M., L. Mošanský, J. Fričová. \& J.C. Casanova. 1999. Comparison of two sampling methods of small mammals in the margin of a lowland forest. Biol. Bratislava. 54: 595- 597.

Tomes, R.F. 1860. Notes on a second collection of Mammalia made by Mr. Fraser in the Republic of Ecuador. Proc. Zool. Soc. London. 1860: 211-221.

Walker, E.P. 1975. Mammals of the World. The Johns Hopkins University. Baltimore, Maryland. 1500 p. 
